Historic, Archive Document

Do not assume content reflects current scientific knowledge, policies, or practices. 



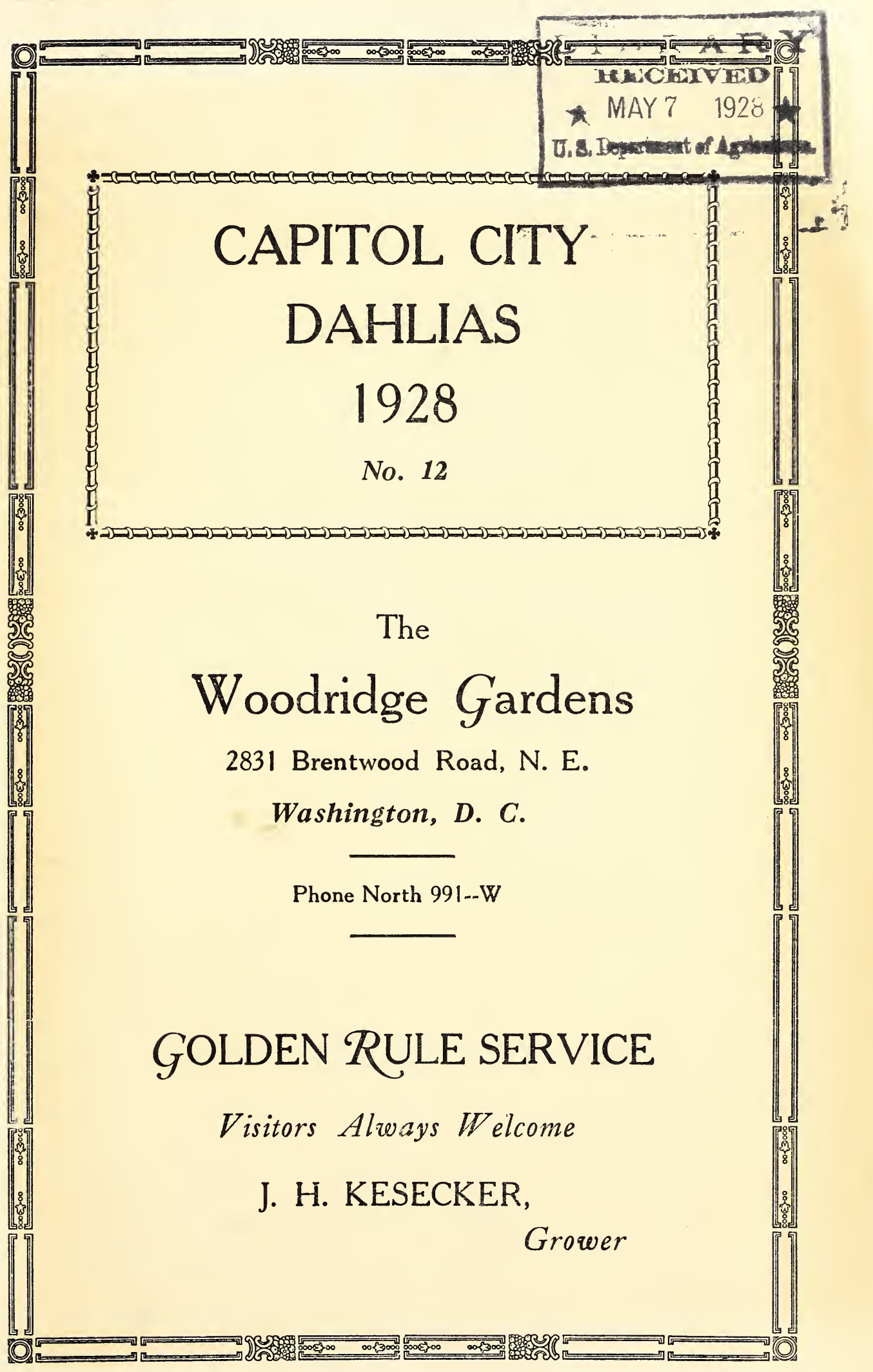




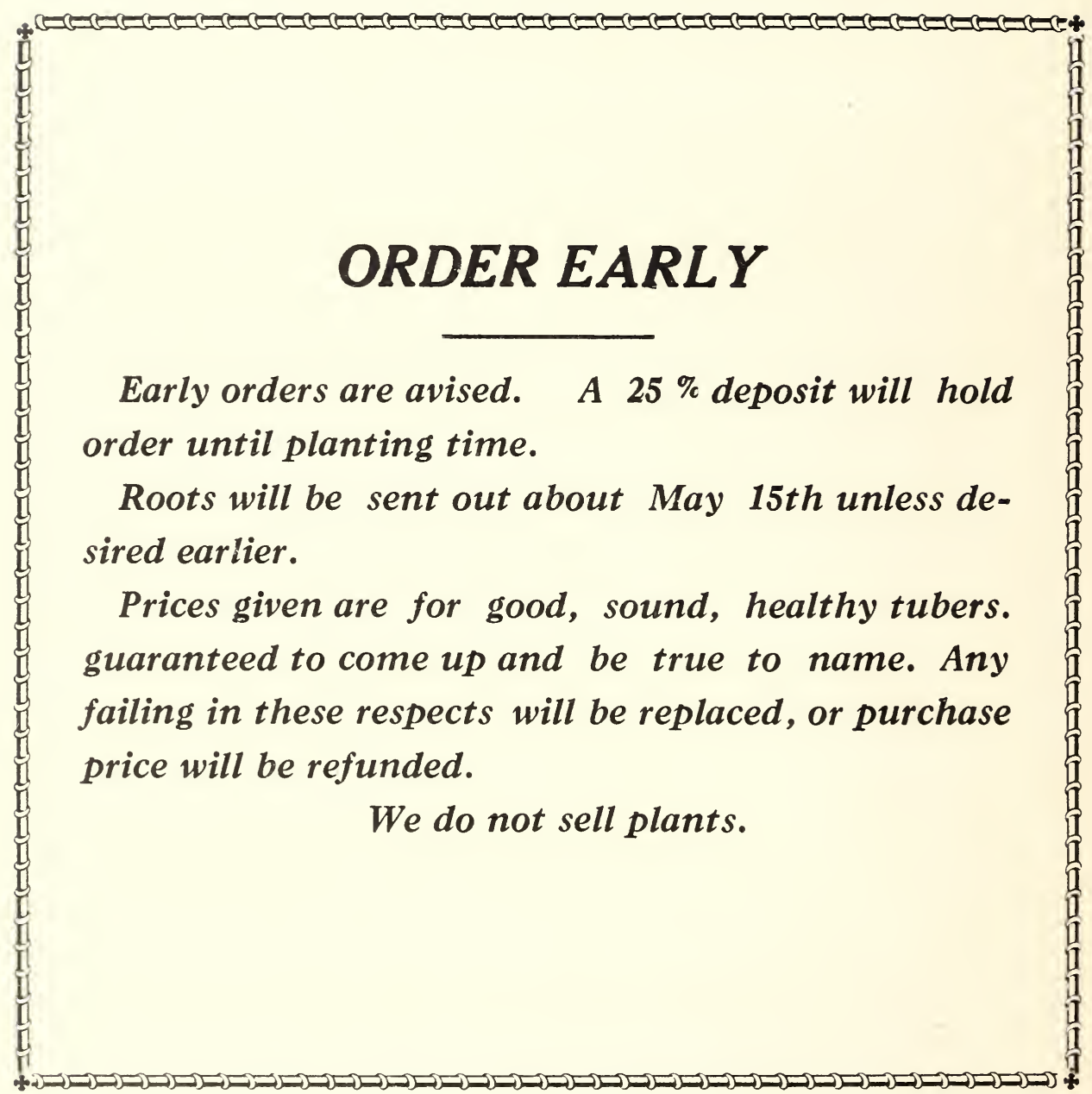




\section{OUR OWN INTRODUCTION}

We invite special attention to the following seven dahlias of our own introduction and dissemination, all of which are commended with the utmost confidence.

OUR OWN INTRODUCTIONS ARE PROPAGATED FROM TUBERS ONLY, WHICH SHOULD INSURE BEST POSSIBLE STOCK.

JACK CUR'TIS (Curtis-Kesecker), H. C. 10-12 inches. This wonderful dahlia again won First at all the shows entered in 1927; was awarded sweepstakes prize, a silver cup, and various ribbons, and attracted the crowds at the shows and at our gardens. If you want to win, either for size or for best dahlia, get Jack Curtis. Grows up to eleven and twelve inches across without forcing. We never force. It is a long-season bloomer, and last fall kept up its size and airtight centers until killed by frost November 6th-the longest dahlia season we have ever had! By November first about everything else was throwing open centered flowers, yet Jack Curtis did not show an open center, and the size was running around eight inches.

The color is a very dark, velvety maroon with lighter reverse-one of the richest colors imaginable.

The bush grows a medium height and is crowned with the big flowers from early season until late.

We only propagate these fine dahlias from tubers-no cuttings; hence maximum vitality and strength. Jack Curtis has never stunted.

Only one hundred tubers will be put out this spring and the price per

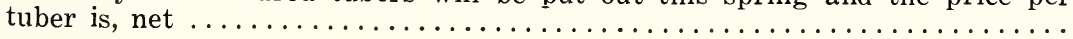

JACKIE BOY (Curtis-Kesecker), D., 8 inches. A brilliant flower of rich, deep, American Beauty Rose. This is our tallest dahlia, growing 9 to 10 feet. The big blooms may be had with stiff, heavy, leafy stems three feet long. Most desirable for decorative purposes and florists' highest grade use, the

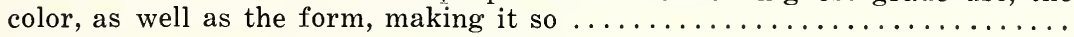

MR. Z. D. BLAKISTONE (Kesecker), H. C. 8 inches. This big hybrid cactus is named in honor of the first president of the National Capital Dah ia and Iris Society, one of our leading florists, and a most ardent lover of fine dahlias. It is a clear pink, shading lighter towards the edges; well positioned on a stiff stem. Keeps up its large size from early until late and should prove a

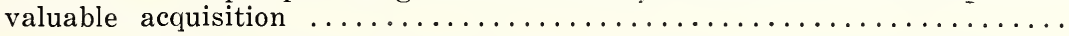

MRS. JAMES R. CARMER (Kesecker), H. C. 8 inches. A charming dahlia of rich autumn tints and flushed sunset shades, with dark, conpery center. One of those flowers that shows up so well under artificial light. A clean grower

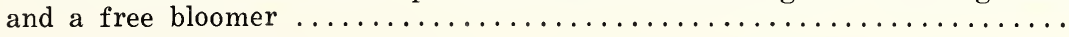

NELLIE CURTIS (Curtis-Kesecker). A very unusual flower of rich burnt orange heavily shaded to a sweet shrub center. The big blooms with petals curved back to the stems suggest great bronzy chrysanthemums ........

THE D. A. R. (Kesecker). 7 inches. The D. A. R. is a lively orchid pink with a deeper center. The medium sized fluffy flowers are more suggestive of choice chrysanthemums than dahlias. The strong, wiry, we'l-foliaged stems carry the flowers in excellent fashion, adarting them most beautifully for cut flower purposes and florists' use. One florist bought all we had last year. Another pronounced it "The finest florist flower in this who'e show." The bush grows low and spreading with many base branches, hence many flowers.

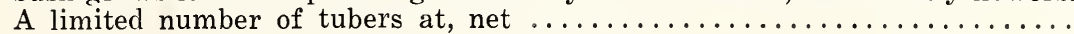


UNCLE JIM CARMER (Kesecker). 8 inches. Uncle Jim still holds first place in our gardens as the most intensely brilliant crimson, dazzling the eye with its marvelously rich coloring. The big, deep, heavy blooms stand proudly above the foliage and attract first attention of visitors. The demand for this dahlia at the gardens last year was again so great that we only have a few

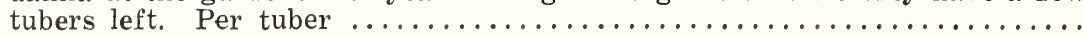

In conjunction with Mr. M. S. Curtis, of the Mahoning Dahlia Gardens, Youngstown, Ohio, we are expecting to intrcduce some other very remarkable new creations next year which have been under rigid tests and strict observation for the past two years and which give assurance of unusual merit. Watch for them! 


\title{
GENERAL COLLECTION
}

\author{
ABBREVIATIONS \\ C.-Cactus; D.-Decorative; H. C.-Hybrid Cactus; P.-Peony. \\ PRICES ARE FOR STRONG TUBERS, FULLY GUARANTEED
}

AL KORAN (D.). Yellow, suffused goldenrod. Very large $\ldots \ldots \ldots \ldots \ldots \ldots . \$ \$ 1.00$

AMULET (D.). Rich, deep brown of fine form. Free bloomer ......... 2.50

BALLET GIRL (C.). Orange, tipped white, with variations $\ldots \ldots \ldots \ldots \ldots \ldots . \quad \mathbf{1 . 0 0}$

BAZAAR (D.). Most beautiful. Sunset shades, scarlet and gold ......... $\mathbf{1 . 5 0}$

RELVEDERE (D.). Deep, velvety red. One of our darkest .......... 2.00

BEN WILSON (D.). Orange scarlet and gold. Very large ............ 1.00

ELACK JACK (D.-P.). Deep maroon, aimost black. Very 'arge and very tall . $\mathbf{1 . 5 0}$

BLUE LADY (D.). A large flower of bluish lavender shading to white. Fine

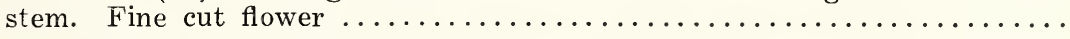

BON RAY (D.). A "very best" red, of gigantic size. Fine bloomer, fine keeper. Foliage right up to the big crimson flower. Does not sun-bleach. Keeps on the bush for weelss. Stems hard and straight and stiff. One of the finest

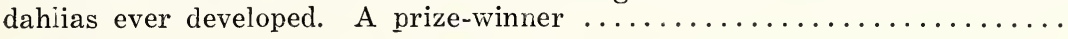

BUTTERCUP (D.), Clear lemon yellow. Very large ................. 1.00

C. HUBER (D.). An unusual begonia red of large size. Stiff hard stems .... $\quad \mathbf{2 . 5 0}$

CARDINAL (D.). Bright, vivid red on a heavy stem $\ldots \ldots \ldots \ldots \ldots \ldots \ldots \ldots$

CHAMPAGNE (D.). A "highest grade" dahlia in every way. Champagne co'or toning to a pretty pink center. A well-orcened flower on top of a perfect

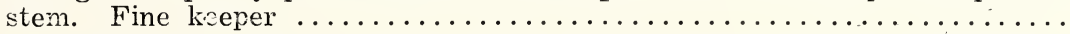

CHEMAR'S CHARM (D.). Has the habits of Jersey's Beauty. Salmon pink.

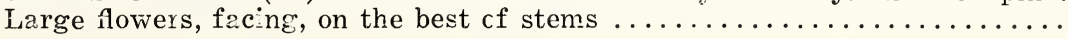

CHEMAR'S MASTERPIECD (C.). A huge incurved cactus of orchi-1 pink. Extra large flowers, of perfect form, on extra long stem. Ten-inch flowers in

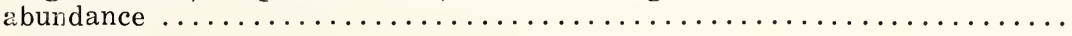

CHEMAR'S PURTT (D.). Said to be a most perfect decorative seedling from Jersey's Eeauty, which it resembles in everything but color. The petals are long and straight, the center excellent, the size immense; stems extra long,

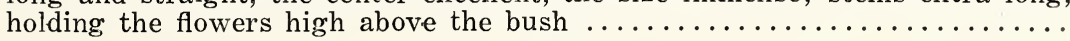

CHEMAR'S QUEEN (D.). A very large, bright yellow. Average 9 inches. The flowers are he'd perfectly erect 
CHEMAR'S U.S. A. A U. S. A. with a long, stiff stem, holding the large, tightcentered flower in erect fashion. Color like the parent: apricot, suffused buff

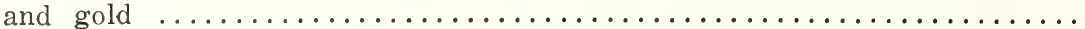

CIGAREITE (H. C.). Creamy white, edged orange, with variations. Large

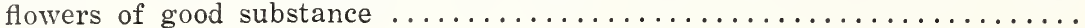

CONCHITA (D.). A most beautiful pink of good size, and a very free bloomer.

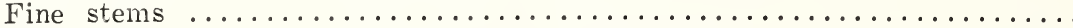

CORONA (D.). A miniature decorative of perfect form. Sometimes called the carnation flowered dahlia. Resembles carnations at a little distance. Pure white

$50 \mathrm{c}$

UADDY BUTLER (H. C.). A fine hybrid cactus good for cut flowers as well as exhibition. Rosy carmine with lighter reverse, the twisted petals showing

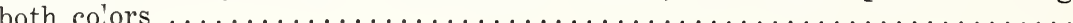

DARDANELLA (D.). Unusually pretty. Big fluffy flowers of scarlet and gold

DOCTOR A. L. HOUSE (D.). A rich red of unusual formation and color. Very

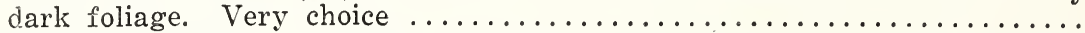

EARL WILLIAMS (D.). Large flowers of deep formation. Brilliant orange scarlet, each petal splashed white. Unusually showy and desirable. $\$ 1.50,3$ for $\$ 3.00$

EL DORADO (D.). A one-hundred-per-cent. dahlia. Vivid gold deepening and carkening toward the center. Of great substance on long, straight stems. A very free b'oomer, and should be in every collection ...............

EL GRENADA (H. C.). Vivid orange; creamy reverse. Petals twist and turn showing two-color effect. A very free bloomer and a wonderful

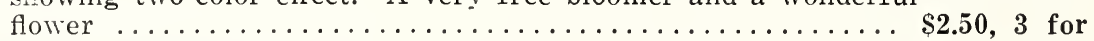

ELLINOR VANDERVEER (D.). The best pink dahlia we have ever grown, the blcum from earliest fall to late season being of larre size and pest form. A very free bioomer. Of exquisite beauty and great size. Glowing satiny pink, edgcd lighter shade. Should be in every fine coliection ...........

EMMA MARIE (D.). A clear pink with cream-white center -...............

FIRELIGHT (D.). An unusual flower composed of very broad petals of pale yellow, each petal tipred red. Stiff stems. Immense foliage ...........

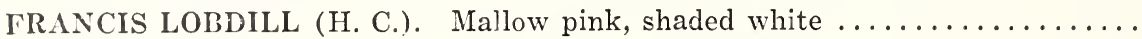

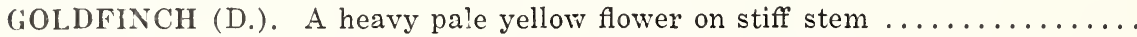

HARRY SHELDON, JR. (D.) A big, broad-petaled beauty. Outer portion white, middle lilac blush, center creamy white. Late in season a pure white.

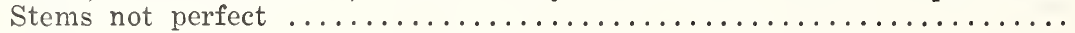

HELEN KELLER (P.). A large, handsome rose-pink. Weak stem ..........

HERCULES (D.). A giant flower. Tangerine blending yellow. Pendant stem

ILLUMINATOR (P.). Bright red. Immense size. Very free .............

ISLAM PATROL (H. C.) One of the prettiest flowers imaginab'e. Dark, tap-

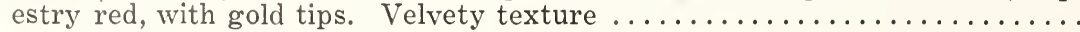

J. W. DAVIES (D.). Deep cerise, gradually lightening toward outer edges .... 
JEAN CHAZOT (C.). Beautiful nasturtium red. Free bloomer. A fine keeper.

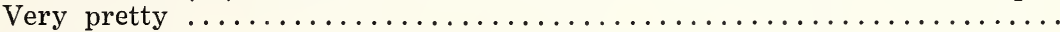

JERSEY'S BEACON (D.). Chinese scarlet. Paler reverse. Very pretty ....

JERSEY'S BEAUTY (D.). One of the best dahlias in the world, of erosine pink. The perfect flowers are borne high on unusually long, stiff stems. A most excellent keeper ......................\$1.50, 3 for

JERSEY'S KING (D.). Begonia rose. A heavy, full, flower on a stiff stem .....

JESSIE K. PRESCOTT (D.). An unusual flower of deep reddish orange at center, gradually shading to buff at the edge $\ldots \ldots \ldots \ldots \ldots \ldots \ldots \ldots \ldots$

JUDGE MAREAN (D.). A fine blending of salmon, red, orange, yellow and

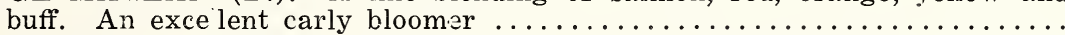

JUNIOR (D.). An enormous flower of pure lavender and great beauty. Curved

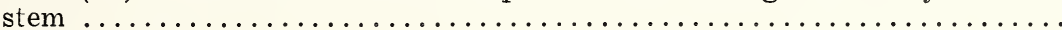

KATHERINE VALENTINE (D.). Clear salmon, tinted orange buff. Best stems

MARIPOSA (H. C.). We esteem this one of the world's best dahlias. One of our best bloomers, running from very early summer until frost, keeping up its size. A refined shade of pinlk, suffused violet $\ldots \ldots \ldots \ldots \ldots \ldots \ldots$

KITTY DUNLAP (D.). American Beauty color. Fine keeper ..............

LOLITA VELASCO (C.). A perfect white cactus of medium size. Plant early

LOTUS (D.). Always a favorite. An early and a persistent bloomer. Resembles

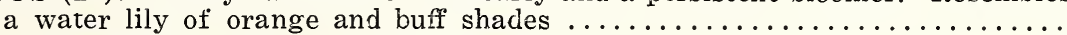

LOUISE SLOCUMB (D.). A medium-sized flower of rich garnet on a good stiff

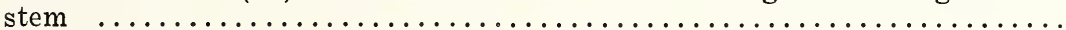

MARGARET KENNER (C.). One of the handsomest flowers imaginable-clear pink, the extra-long petals standing out in beautiful star fasnion. Stems

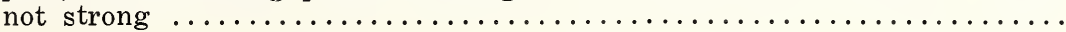

MARGARET MASSON (D.). Silvery rose. Wide peta's. Hard, st'ff stems ...

MARGARET WOODROW WILSON (D.). Opalescent pink. Extra broad petals.

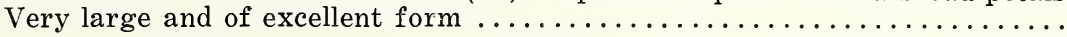

MARMION (D.). Of enormous size and depth. Pure, golden yellow with bronzy

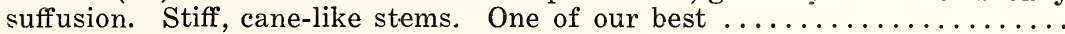

MOORKOP. Miniature Decorative, flowers, 21/2 inches. Imported. Unusually pretty. Loose, gardenia-like formation. Blooms of richest velvety crimson

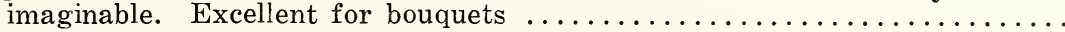

MR. C. H. DRESSELHUY'S (D.). A delicate shade of rose pink, toning to silver at euge. lilost cxcelient cut Hower for florists $\ldots \ldots \ldots \ldots \ldots \ldots \ldots \ldots \ldots \ldots$

MR. CROWLEY (D.). Bright, glowing, salmon pink; yellow at base. Stiff

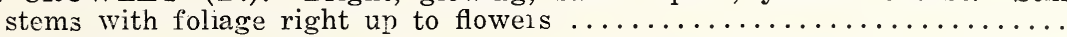

MRS. CARL SALSBACH (D.). Mauve pirk, on long, stiff stems . ..........

MRS. E. P. JUDD (D.). Enormous flowers of old rose, overlaid pink. Stems

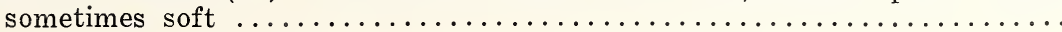


MRS. ELEANOR MARTIN (D.) One of the finest decoratives, the blooms all being large, and on the best of stems. A beautiful mulberry, suffused with golden tints. Free bloomer. A handsome bush. Sure to please .....

MRS. GEORGE W. ELKINS, JR. (H. C.) A very large, heavy flower of old rose

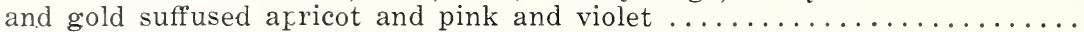

OUR COUNTRY (D.). An immense, fantastic flower of purple, tipped snow

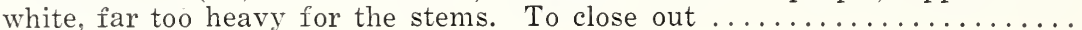

PACIFIC GLOW (P.). Delicate shell pink, tinged rose. An immense flower.

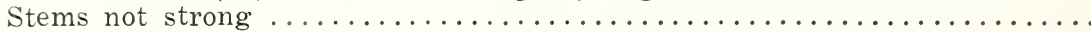

PATRICK OMARA (D.). Ripe apricot shaded to a darker center. Perfect

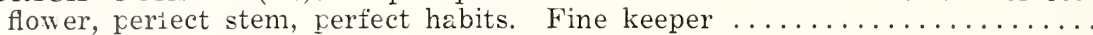

PAUL REVERE (D.). Bright crimson. Very large, full and deep ............

PiMLico (D.). An unusuaily fine develorment of Mr. E. P. Loller, president of the Baltimore (Md.) Dahlia Society. A first nrize vinrer last year. Buff and orange. A very large and deep flower, held erect on a perfect stem.

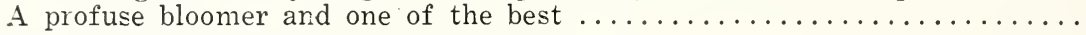

QUEEN OF THE GARDEN BEAUTIEUL (D.). Truly a giant. Has grown to 12 inches. Lemon, shaded cream, on a straight stem .............

RADIO (D.). Another giant growirg 9 inches. Blood red, edged yellow. Stiff

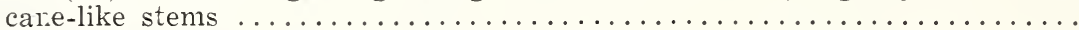

RODMAN WANAMAKER (P.). Bronzy salmon pink. Very showy ard much

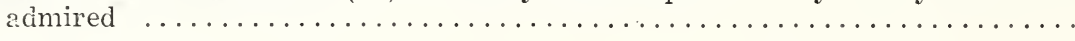

ROLLO BOY (H. C.). Of great size with every flower carried high on a strong

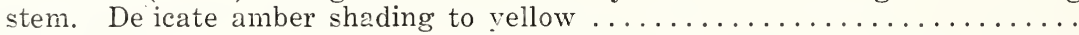

ROMAN EAGLE (D.). A most handsome flower of brilliant burnished copper.

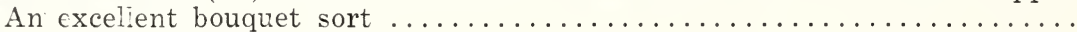

ROSA NELL (D.). An extra large flower of deep rose on an exira long stiff

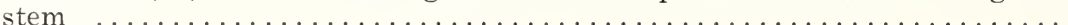

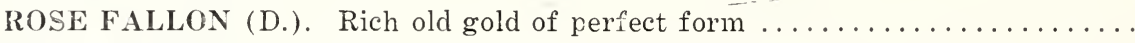

SAGAMORE (D.). A big flower of lovely yellow gold, shaded to a darker center.

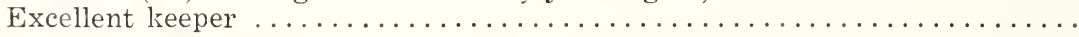

SANHICAN'S MONARCH (D.). Deep, dark tyrian rose, shaded lighter at

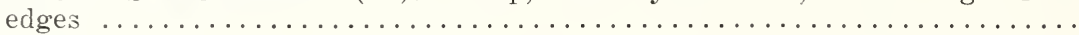

SARHICAN'S ROSE (D.). Clear, rose-pink. Rounded, curled peta's. A very

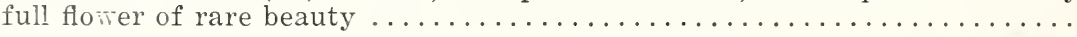

SANHICAN'S RUBY (D.). Bright, ruby red, full of fire $\ldots \ldots \ldots \ldots \ldots \ldots$

ECRETARY WORK (H. C.). Rich old gold of unusual shade. A free b'oomer.

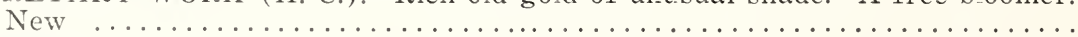

SENORITA (D.). Bright, poinsettia red. Tufted petals. One of the handsomest

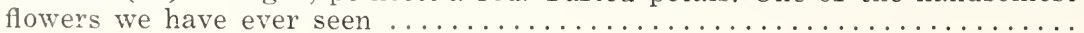

SHANNON (D.). Orange buff of good size. Fine cut flower. Fine stem. Keeps well 
SHUDOW'S LAVENDER (D.). Always a favorite. Silvery lavender over'aid

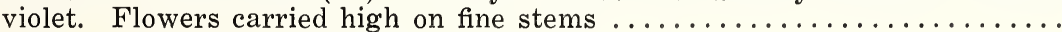

SNOWDRIFT (D.). The whitest dahlia extant. Very large $\ldots \ldots \ldots \ldots \ldots \ldots$

SOMERSET (D.). A unique shade of salmon and old rose. Unusual form.

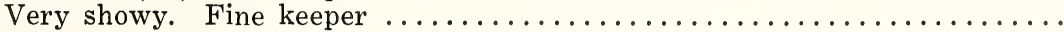

SOROSIS (D.). Deep, rich, red. Dwarf grower, but free bloomer ...........

ST. FRANCIS (D.). Soft cream, with pink glow. Handsome .............

SUN MAID (H. C.). One of our prettiest flowers. Very large, very free. Orange

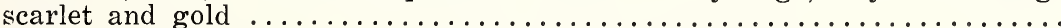

THE BASHFUL GIANT (D.). Straight stiff stems. A giant flower of blush apricot. We have developed a stock of this wonderful flower that carries the blooms on stiff, siraight stems, the mammoth blooms facing. Very choice

THE CUMBERLAND (D.). Deep, velvety red, carried high on perfect stems. Fine cut flowers

THE EMPEROR (D.). A perfect flower on a perfect stem. Deep maroon. A high grade dahlia ........................ $\$ 1.00,3$ for

THE WIZARD OF OZ (D.). A big flower of glowing satiny amber pink or

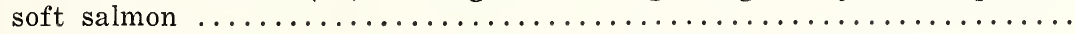

TOMMY ATKINS (D.). Flaming scarlet, full of metallic luster ............

TRENTONIAN (D.). Rich, coppery bronze of marvelous brilliancy. Stems

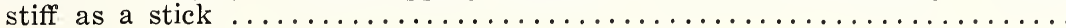

VALLEY FORGE (D.). Brilliant fuchsia garnet. Very early and very free $\ldots \ldots \ldots \ldots \ldots \ldots \ldots \ldots \ldots \ldots \ldots \ldots \ldots \ldots \ldots \ldots \ldots \ldots \ldots \ldots \ldots \ldots \ldots \ldots, 3$ for

WILliAM G. (H. C.). A massive bloom running up to eleven inches across.

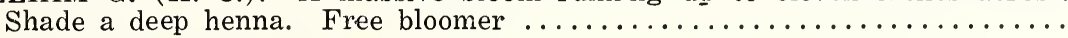

WORLD'S BEST WHITE (D.). We still regard this as the best white dahlia ever developed. Big, heavy, broad-petaled flowers on long, stiff stems above most luxuriant foliage. Always in demand as a cut flower, $\$ 2.00,3$ for

YELLOW DE LUXE (D.). A big, clear canary flower of pretty form on good stems. An abundance of large, perfect blooms. A scarce variety ......... 



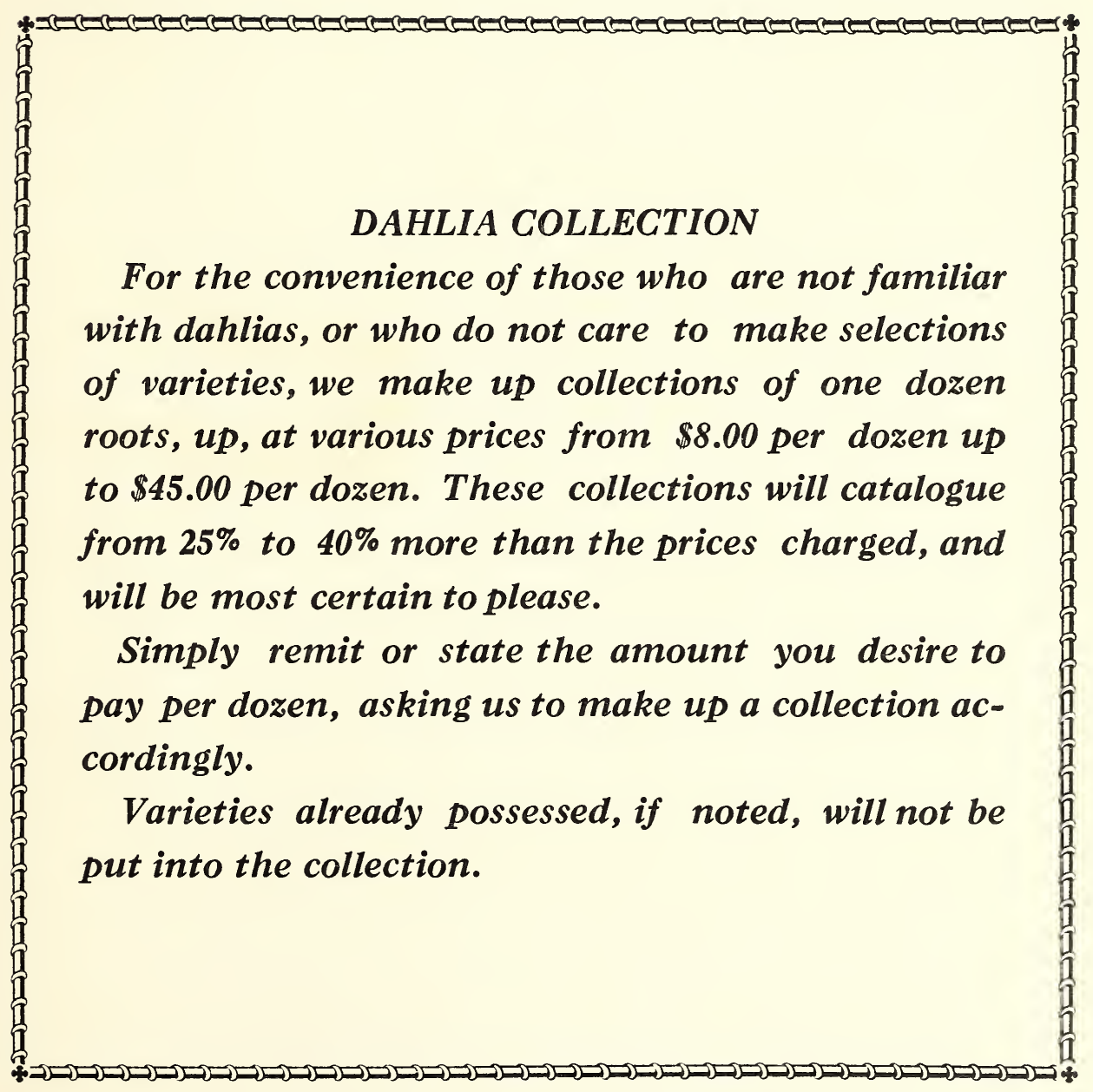


